\title{
Protein enrichment of wheat flour doughs: empirical rheology using protein hydrolysates
}

\author{
Amanda de Cássia NOGUEIRA ${ }^{1}$ (D), Renata Alves de OLIVEIRA ${ }^{1}$, Caroline Joy STEEL ${ }^{1 \star}$
}

\begin{abstract}
Protein enrichment of bakery products not only improves protein ingestion, but also compensates for the deficiency of certain limiting amino acids in these products. However, the addition of protein sources can greatly influence the characteristics of the dough and, consequently, process and product parameters. Thus, the objective of this work was to evaluate the rheological behavior of wheat flour doughs enriched with whey and collagen protein hydrolysates. Both hydrolysates influenced rheological properties of wheat flour doughs. They reduced water absorption and increased arrival time and dough development time, but caused a weakening of the dough when compared to the control. However, a greater influence of collagen hydrolysate was observed when compared to whey hydrolysate. Regarding pasting properties, the hydrolysates led to a decrease in all parameters, except pasting temperature. These results allow predicting the behavior of doughs enriched with these protein sources during processing and directing their application.
\end{abstract}

Keywords: farinograph; RVA; collagen; whey protein.

Practical Application: Protein hydrolysates can be used to improve the protein content of bakery products, but it is necessary to understand their effects on processing conditions. This study does this through rheological analyses of wheat flour doughs enriched with these hydrolysates.

\section{Introduction}

Protein enrichment of bakery products aims to meet the need for compensating the deficiency of limiting amino acids such as lysine. In several foods, lysine is a limiting amino acid, not only because of its lower content in determined proteins, but also as a consequence of secondary chemical changes due to factors such as light, heat, alkali, and reducing sugars, making it a nutritionally unavailable component (Hood-Niefer \& Tyler, 2010). Besides improving their nutritional properties, the enrichment of bakery products with proteins also increases protein intake, making up for this deficiency and meeting the specific needs of target groups and vulnerable segments of the population that are undernourished and malnourished (Gani et al., 2015a).

The use of protein hydrolysates can help enrich wheat flour-based products in relation protein and amino acid contents. In addition, the use of protein hydrolysates may reduce allergenic potential of the added protein, which can often be a worrying factor when it comes to protein enrichment. In theory, extensive hydrolysis may destroy allergenic epitopes, resulting in safe hypoallergenic products (Mahmoud, 1994; Foegeding et al., 2011). Lower levels of hydrolysis, in turn, are associated with better functionality in foam formation, emulsification and gelation (Foegeding et al., 2011).

Hydrolyzed proteins have been more widely used in cereal bars, sports drinks, hypoallergenic formulas for children (Foegeding et al., 2011) and fermented milk drinks (Gerhardt et al., 2013). The meat industry has also used them as an emulsion constituent for the manufacture of products such as hot dogs and bologna sausages (Prestes, 2013; Cavalheiro et al., 2014), among others. In bakery products, their application is not so common.

The study of the enrichment of bakery products goes through several stages, such as the study of the empirical rheology of the wheat flour doughs, the processing and, finally, the technological, sensorial and nutritional characteristics of the final product. Thus, the study of the empirical rheology of wheat flour doughs with the addition of protein hydrolysates is very important, not only because it is the initial stage and aims to predict their behavior in the process, but also because the hydrolysates are little explored in this scope. In addition, generally studies with relatively low concentrations are found: up to $15 \%$ of whey protein hydrolysate (Gani et al., 2015a; 2015b); up to $4.5 \%$ of collagen protein hydrolysate (Menezes et al., 2014); up to 20\% of soy protein hydrolysates (Schmiele et al., 2017) and up to 3\% of Lima bean and cowpea hydrolysates (Franco-Miranda et al., 2017); all studies, in replacement of wheat flour. We chose to add collagen and whey protein hydrolysates ( 0 to $20 \%$ ) to wheat flour and to evaluate the rheological behavior of the doughs produced, not only because of the desired properties of these hydrolysates (high protein content, amino acid content, lower allergenicity, foaming properties, emulsification and gelation), but also because of the differences in their composition. In addition, the association of their proteins, with different amino acid compositions, may improve the nutritional value of food. 


\section{Materials and methods}

\subsection{Material}

Wheat flour (WF), hydrolyzed whey protein (HW) (Doremus, São Paulo, Brazil - defined as hydrolyzed protein from whey), and hydrolyzed collagen protein (HC) (NOVAPRO Hydro, NovaProm, São Paulo, Brazil - defined as hydrolyzed protein from bovine collagen), were used.

\subsection{Methods}

\section{Characterization of raw materials}

The chemical composition (moisture, protein, lipid and ash contents) of wheat flour was determined according to AACCI (American Association of Cereal Chemistry International, 2010) methods. For protein hydrolysates, the same analyses were performed according to AOAC (Association of Official Analytical Chemists, 2006). Wheat flour was also characterized regarding its wet and dry gluten contents, gluten index and falling number by methods 38-12.02 and 56-81.03 of AACCI (American Association of Cereal Chemistry International, 2010), while the farinograph and pasting properties were characterized as explained in 2.2.3.

The amino acid profile of the protein hydrolysates was also determined, using the method described by White et al. (1986) and Hagen et al. (1989). Tryptophan content was measured according to Lucas \& Sotelo (1980). The chemical score was also calculated by dividing the amino acid content values, in $\mathrm{mg}$ amino acid per gram of protein, by the FAO/WHO (Food and Agriculture Organization \& World Health Organization, 1985) adult standard.

\section{Experimental planning}

To evaluate the effect of different concentrations of $\mathrm{HW}$ and $\mathrm{HC}$ on wheat flour dough rheological characteristics, the independent variables (HW and $\mathrm{HC}$ ) ranged between 0 and 20\%, in substitution of WF (premixes). Tests followed a $2^{2}$ central composite rotational design (CCRD), with four factorial points, four axial points, and three central points, totaling 11 tests. A control test without the addition of hydrolysates was also performed.

\section{Rheological characterization of premixes}

Farinograph properties

Farinograph properties were determined, in triplicate, following the method 54-21.01 of AACCI (American Association of Cereal Chemistry International, 2010), using a Brabender farinograph (Duisburg, Germany), model 827505, to evaluate water absorption (WA), arrival time (AT), dough development time (DDT), stability (S), and mixing tolerance index (MTI). The time of analysis was extended until all parameters of analysis were obtained, with maximum running time of 60 minutes. It is worth highlighting that two curves did not complete within 60 minutes (tests 4 and 8), making it impossible to measure MTI values, which ended up being considered zero. The maximum running time allowed by the equipment was of 60 minutes.

\section{Pasting properties}

Pasting properties were determined in a Rapid Visco Analyser (RVA), using the Thermocline for Windows software, version 2.3 (Jessup, USA), and the profile Standard 1, with a sample of $3.5 \mathrm{~g}$, according to method 162 by ICC (International Association for Cereal Science and Technology, 1996). The following parameters were evaluated: pasting temperature, maximum viscosity, trough viscosity, final viscosity, breakdown, setback and peak time.

\section{Statistical analysis}

Results of the evaluation of the effects of different concentrations of $\mathrm{HW}$ and $\mathrm{HC}$ on the experimental planning responses were analyzed using the Response Surface Methodology, with the Statistica 7.0 software (StatSoft, Tulsa, USA). Analysis of variance (ANOVA) $(\alpha \leq 0.10)$ was used to calculate the regression coefficients, with minimum determination coefficient $\left(\mathrm{R}^{2}\right)$ of 0.90 , and calculated $\mathrm{F}>$ tabled $\mathrm{F}$.

\section{Results and discussion}

\subsection{Characterization of raw materials}

Wheat flour presented values of $12.87 \pm 0.04 \mathrm{~g} / 100 \mathrm{~g}$, $10.25 \pm 0.25 \mathrm{~g} / 100 \mathrm{~g}, 0.74 \pm 0.10 \mathrm{~g} / 100 \mathrm{~g}$, and $0.78 \pm 0.01 \mathrm{~g} / 100 \mathrm{~g}$, for moisture, protein (Nx5.7), lipid and ash contents, respectively. Its contents of wet and dry gluten, gluten index and diastatic activity were of $29.53 \pm 0.45 \mathrm{~g} / 100 \mathrm{~g}, 10.39 \pm 0.39 \mathrm{~g} / 100 \mathrm{~g}, 97.68 \pm 0.33$, and $375 \pm 13 \mathrm{~s}$, respectively. HW showed values of $6.68 \pm 0.03 \mathrm{~g} / 100 \mathrm{~g}$, $73.85 \pm 3.31 \mathrm{~g} / 100 \mathrm{~g}, 5.60 \pm 0.56 \mathrm{~g} / 100 \mathrm{~g}$, and $4.60 \pm 0.27 \mathrm{~g} / 100 \mathrm{~g}$ for moisture, protein (Nx6.38), lipid and ash contents, respectively. $\mathrm{HC}$ presented values of $7.12 \pm 0.07 \mathrm{~g} / 100 \mathrm{~g}, 84.98 \pm 1.34 \mathrm{~g} / 100 \mathrm{~g}$, $0.81 \pm 0.03 \mathrm{~g} / 100 \mathrm{~g}$, and $2.52 \pm 0.90 \mathrm{~g} / 100 \mathrm{~g}$ for moisture, protein (Nx5.50), lipid and ash contents, respectively.

The amino acid profile of wheat flour and hydrolysates can be seen in Table 1. In Table 2, the essential amino acids contents in $\mathrm{mg} / \mathrm{g}$ protein and the amino acid chemical score are presented.

As expected, HW presented all essential amino acids (Table 1). In particular, the levels ( $\mathrm{g} / 100 \mathrm{~g}$ protein) of lysine (9.78) and threonine (8.75) stand out, as well as the high value of BCAAs (branched-chain amino acids) (24.64), corresponding to valine (6.46), leucine (11.18) and isoleucine (7.00). Etzel (2004) found approximately 25\% BCAAs in whey protein isolate. $\mathrm{HC}$, due to the predominance of the amino acids glycine (27.88), proline (16.42) and alanine (9.91), and lack of most essential amino acids, is considered a poor protein source for the human diet (Ockerman \& Hansen, 1994; Prestes, 2013). As for lysine, a limiting amino acid in wheat flour, both hydrolysates contribute to correct this deficiency, with a greater contribution of HW.

Also in relation to the essential amino acids (Table 2), HW presented higher levels than the FAO/WHO (Food and Agriculture Organization \& World Health Organization, 1985) recommendation for adults. It also presented values higher than those specified by the Brazilian legislation (RDC 54/2012) (Brasil, 2012) as the reference composition for a food to be denoted as a "source of protein". Regarding the amino acid score, it can be 
said that HW has a high nutritional value, since it presented a chemical score greater than 1.0 for all amino acids.

The hydrolysates provided an increase in protein content, as expected. Protein content of WF of $10.3 \%$ increased in all assays: 14.3 to $33.9 \%$ (theoretical calculation). According to
RDC 54/12 (Brasil, 2012), for a food to be considered a source of protein, it should contain $6 \mathrm{~g}$ of this nutrient in its portion, besides presenting specific levels of essential amino acids, in mg/g protein (Table 2). In relation to this requirement, premixes from assays 2, 4, 6, 7 and 9 presented adequate values for all amino

Table 1. Amino acid profile of wheat flour and whey and collagen hydrolysates.

\begin{tabular}{|c|c|c|c|}
\hline Amino acids (g/100 g protein) & Wheat flour* & Whey hydrolysate & Collagen hydrolysate \\
\hline \multicolumn{4}{|l|}{ Hydrophobic (non-polar) } \\
\hline Glycine & 4.00 & 2.14 & 27.88 \\
\hline Alanine & $3.32-3.51$ & 5.99 & 9.91 \\
\hline Proline & 11.22 & 6.95 & 16.42 \\
\hline Valine $^{\star *}$ & $4.59-4.68$ & 6.46 & 2.59 \\
\hline Leucine $^{\star *}$ & $7.12-8.20$ & 11.18 & 3.41 \\
\hline Total & 36.68 & 42.13 & 62.56 \\
\hline \multicolumn{4}{|l|}{ Aromatic } \\
\hline Phenylalanine & $4.98-5.56$ & 3.34 & 2.35 \\
\hline Tyrosine & $3.02-3.12$ & 3.29 & 0.78 \\
\hline Tryptophan & 2.24 & 1.72 & 0,08 \\
\hline Threonine & $3.12-3.32$ & 8.75 & 1.86 \\
\hline Cystine & $1.37-2.73$ & 2.95 & 1.55 \\
\hline Total & 10.58 & 17.51 & 7.00 \\
\hline \multicolumn{4}{|l|}{ Positively charged } \\
\hline Lysine & $2.54-3.02$ & 9.78 & 4.01 \\
\hline Arginine & $4.00-5.56$ & 2.76 & 8.25 \\
\hline Histidine & $2.24-2.44$ & 1.79 & 0.80 \\
\hline Total & 9.90 & 14.33 & 13.06 \\
\hline \multicolumn{4}{|l|}{ Negatively charged } \\
\hline Aspartic acid + aspartate & 4.78 & 11.50 & 5.99 \\
\hline Glutamic acid + glutamate & $33.95-39.71$ & 19.27 & 11.27 \\
\hline
\end{tabular}

${ }^{*}$ Wheat flour contents from Nunes et al. (2001) and Nogueira (2019); ${ }^{* * B C A A: ~ B r a n c h e d ~ C h a i n ~ A m i n o ~ A c i d s ; ~ B o l d ~ l e t t e r s: ~ e s s e n t i a l ~ a m i n o ~ a c i d s . ~}$

Table 2. Essential amino acids contents and amino acid score for wheat flour and whey and collagen hydrolysates.

\begin{tabular}{|c|c|c|c|c|c|c|c|c|}
\hline \multirow[b]{2}{*}{ Amino acids } & \multicolumn{5}{|c|}{$\mathrm{mg}$ amino acid/g protein } & \multicolumn{3}{|c|}{$\begin{array}{c}\text { Amino acid score } \\
(\mathrm{mg} / \mathrm{g} \text { protein } / \mathrm{mg} / \mathrm{g} \text { protein } \mathrm{FAO} / \mathrm{WHO})\end{array}$} \\
\hline & Wheat flour* & $\begin{array}{l}\text { Whey } \\
\text { Hydrolysate }\end{array}$ & $\begin{array}{l}\text { Collagen } \\
\text { Hydrolysate }\end{array}$ & $\begin{array}{l}\text { Adult FAO/ } \\
\text { WHO } \\
\text { Standard }^{* *}\end{array}$ & $\begin{array}{c}\mathrm{RDC} \\
54 / 2012^{* * *}\end{array}$ & $\begin{array}{l}\text { Wheat } \\
\text { flour }\end{array}$ & $\begin{array}{l}\text { Whey } \\
\text { hydrolysate }\end{array}$ & $\begin{array}{l}\text { Collagen } \\
\text { hydrolysate }\end{array}$ \\
\hline Histidine & 23 & 18 & 8 & 16 & 15 & 1.4 & 1.1 & 0.5 \\
\hline Isoleucine & 40 & 70 & 16 & 13 & 30 & 3.1 & 5.4 & 1.2 \\
\hline Leucine & 76 & 112 & 34 & 19 & 59 & 4.0 & 5.9 & 1.8 \\
\hline Methionine + Cystine & 38 & 54 & 24 & 17 & 22 & 2.2 & 3.2 & 1.4 \\
\hline $\begin{array}{l}\text { Phenylalanine }+ \\
\text { Tyrosine }\end{array}$ & 83 & 66 & 32 & 19 & 38 & 4.4 & 3.5 & 1.7 \\
\hline Threonine & 32 & 87 & 19 & 9 & 23 & 3.6 & 9.7 & 2.1 \\
\hline Tryptophan & 22 & 17 & 1 & 5 & 6 & 4.4 & 3.4 & 0.2 \\
\hline
\end{tabular}

${ }^{\star}$ The values of amino acids contents correspond to averages of values presented in Table 1. ${ }^{\star \star}$ Food and Agriculture Organization \& World Health Organization (1985); ${ }^{\star \star \star}$ Reference composition of the Brazilian legislation (Brasil, 2012). 
acids. The other assays did not reach the contents required for some of them; however, the values observed are close to the limits established. The increase of lysine levels in relation to the control is worth mentioning as, in some assays, double (assays 4, 7 and 9) or more (assays 2 and 6) of the value in WF was reached. Threonine levels also increased significantly. Thus, the premixes proved to have a good amino acid profile for the manufacture of wheat flour based products. And the higher the protein content of the raw materials the better, since losses during processing can occur; for example, due to the complexation of amino acids with other compounds.

Moreover, regarding the differences between the amino acids composition of the hydrolysates (Table 1), it is worth mentioning the higher content of hydrophobic amino acids in $\mathrm{HC}$, due to its high glycine, alanine and proline contents, and also the higher levels of aromatic, polar and charged amino acids in HW. This distribution has great importance in the conformation of the proteins and, consequently, influences the interactions established. It is known that the main driving force of protein folding, for example, comes from the hydrophobic interactions of non-polar amino acids (Damodaran et al., 2008). As well as the fact that the higher the number of charged residues, the greater the hydration capacity or the water binding capacity of the protein (Damodaran et al., 2008).

Furthermore, it is known that the addition of protein sources brings changes in the behavior of the product, which in most cases limits their use. Thus, rheological behavior helps to predict these modifications, as can be seen below.

\subsection{Rheological characterization of premixes}

\section{Farinograph properties}

All farinograph parameters presented mathematical models capable of predicting the behavior of WF doughs replaced by HW and HC. Results can be observed in Table 3. The response surfaces, as well as their mathematical models, can be observed in Figure 1 and Table 4, respectively.

In general, the substitution of WF by $\mathrm{HC}$ and $\mathrm{HW}$ reduced water absorption (WA) (Figure 1a). However, a greater effect was observed for HC. For the tests, WA values ranged between 40.1 and $60.4 \%$; while for the control, WA was $63.9 \%$ (Table 3). At the higher substitutions of WF by HC, regardless of the amount of flour replaced with HW, the WA was lower. Regarding $\mathrm{HW}$, water absorption remained high for almost all substitution percentages tested (at low levels of substitution of HC). This can be observed where we have the highest substitution percentages of both hydrolysates, in which we obtained the lowest WA. The lower values of WA are probably due to water immobilization caused by hydrolysates. In addition, this decrease is associated with a decrease in molecular weight (hydrolysates have lower molecular weight) and a decrease in viscosity. The presence of soluble proteins tends to require a smaller amount of water in

Table 3. Matrix of the experimental design and farinograph parameters as a function of the substitution of wheat flour by whey and collagen protein hydrolysates.

\begin{tabular}{|c|c|c|c|c|c|c|c|c|c|}
\hline \multirow{2}{*}{ Tests } & \multicolumn{2}{|c|}{ Coded variables } & \multicolumn{2}{|c|}{ Real variables } & \multicolumn{5}{|c|}{ Farinograph parameters } \\
\hline & HW & $\mathrm{HC}$ & $\mathrm{HW}^{*}$ & $\mathrm{HC}^{*}$ & WA (\%) & $\mathrm{AT}(\min )$ & DDT (min) & $\mathrm{S}(\mathrm{min})$ & MTI (BU) \\
\hline 1 & -1 & -1 & 2.9 & 2.9 & $57.0 \pm 0.3$ & $5.7 \pm 0.8$ & $10.7 \pm 0.6$ & $7.7 \pm 0.4$ & $78.3 \pm 10.4$ \\
\hline 2 & +1 & -1 & 17.1 & 2.9 & $54.2 \pm 0.4$ & $17.0 \pm 1.1$ & $19.2 \pm 1.0$ & $4.5 \pm 0.4$ & $75.0 \pm 5.0$ \\
\hline 4 & +1 & +1 & 17.1 & 17.1 & $40.1 \pm 0.6$ & $55.0 \pm 1.3$ & $59.8 \pm 0.3$ & $5.0 \pm 1.3$ & $0.0 \pm 0.0$ \\
\hline 5 & $-1.41\left(-a^{* *}\right)$ & 0 & 0 & 10 & $49.5 \pm 0.3$ & $10.6 \pm 0.7$ & $17.0 \pm 2.1$ & $19.1 \pm 0.4$ & $20.0 \pm 0.0$ \\
\hline 8 & 0 & $+1.41\left(+a^{\star *}\right)$ & 10 & 20 & $40.7 \pm 0.2$ & $47.4 \pm 1.4$ & $56.7 \pm 1.7$ & $12.4 \pm 1.5$ & $0.0 \pm 0.0$ \\
\hline $9(\mathrm{C})$ & 0 & 0 & 10 & 10 & $49.7 \pm 0.6$ & $27.4 \pm 2.7$ & $30.2 \pm 2.9$ & $7.6 \pm 0.2$ & $36.7 \pm 10.4$ \\
\hline $10(\mathrm{C})$ & 0 & 0 & 10 & 10 & $49.4 \pm 0.6$ & $24.0 \pm 0.1$ & $26.7 \pm 0.6$ & $7.8 \pm 0.8$ & $37.3 \pm 6.4$ \\
\hline $11(\mathrm{C})$ & 0 & 0 & 10 & 10 & $49.7 \pm 0.6$ & $24.4 \pm 0.2$ & $27.3 \pm 0.3$ & $8.1 \pm 0.8$ & $36.7 \pm 2.9$ \\
\hline Control & - & - & 0.0 & 0.0 & $63.9 \pm 0.4$ & $1.4 \pm 0.05$ & $14.4 \pm 0.05$ & $20.7 \pm 0.6$ & $43.3 \pm 5.8$ \\
\hline
\end{tabular}

Averages \pm standard deviations. Where: HW: hydrolyzed whey protein; HC: hydrolyzed collagen protein; ${ }^{\star}$ Substitution percentage of wheat flour; WA: water absorption; AT: arrival time; DDT: dough development time; S: stability; MTI: mixing tolerance index; (C): central point; Control: pure wheat flour $\left(\right.$ without addition of hydrolysates); ${ }^{*} \alpha=\left(2^{\mathrm{n}}\right)^{1 / 4}$, where $\mathrm{n}$ $=$ the number of independent variables; in this case, $\mathrm{n}=2$ and $\mathrm{a}=1.41$.

Table 4. Coded models for farinograph parameters as a function of the substitution of wheat flour by whey and collagen protein hydrolysates (coded values of the independent variables must be used).

\begin{tabular}{cl}
\hline Parameters & Coded models \\
\hline Water absorption (\%) & $=49.58-1.80 \mathrm{x}_{1}-1.18 \mathrm{x}_{1}^{2}-6.81 \mathrm{x}_{2}+0.55 \mathrm{x}_{2}^{2}\left(\mathrm{R}^{2}=0.99 ;\right.$ Fcalc/Ftab $\left.=104.32\right)$ \\
Arrival time $(\min )$ & $=26.28+6.82 \mathrm{x}_{1}+15.76 \mathrm{x}_{2}\left(\mathrm{R}^{2}=0.99 ; \mathrm{Fcalc} / \mathrm{Ftab}=12.76\right)$ \\
Dough development time $(\mathrm{min})$ & $=27.86+5.72 \mathrm{x}_{1}+17.50 \mathrm{x}_{2}+4.26 \mathrm{x}_{2}^{2}\left(\mathrm{R}^{2}=0.98 ; \mathrm{Fcalc} / \mathrm{Ftab}=22.04\right)$ \\
Stability $(\min )$ & $=7.86-4.00 \mathrm{x}_{1}+2.59 \mathrm{x}_{1}^{2}+2.78 \mathrm{x}_{2}-2.93 \mathrm{x}_{1} \mathrm{x}_{2}\left(\mathrm{R}^{2}=0.95 ; \mathrm{Fcalc} / \mathrm{Ftab}=5.84\right)$ \\
Mixing tolerance index $(\mathrm{BU})$ & $=36.64-30.01 \mathrm{x}_{2}\left(\mathrm{R}^{2}=0.90 ; \mathrm{Fcalc} / \mathrm{Ftab}=16.30\right)$ \\
\hline
\end{tabular}

$\mathrm{x}_{1}=$ coded value $(-\alpha$ to $+\alpha)$ of hydrolyzed whey protein $(\mathrm{HW})$ concentration in substitution percentage of wheat flour $($ WF $)$; $\mathrm{x}_{2}=$ coded value $(-\alpha$ to $+\alpha)$ of hydrolyzed collagen protein (HC) concentration in substitution percentage of wheat flour (WF); Fcalc = calculated F; Ftab = tabled F. 
(a)

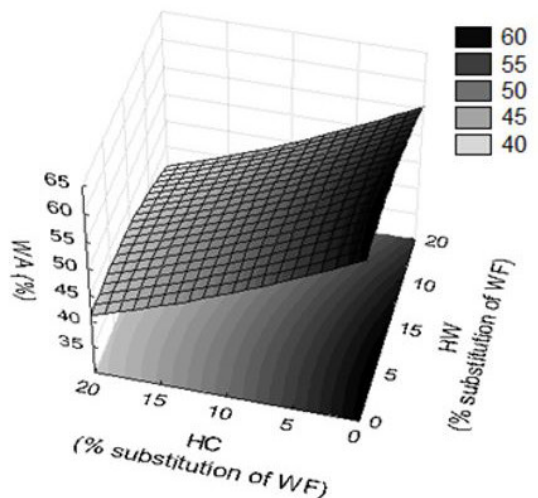

(b)

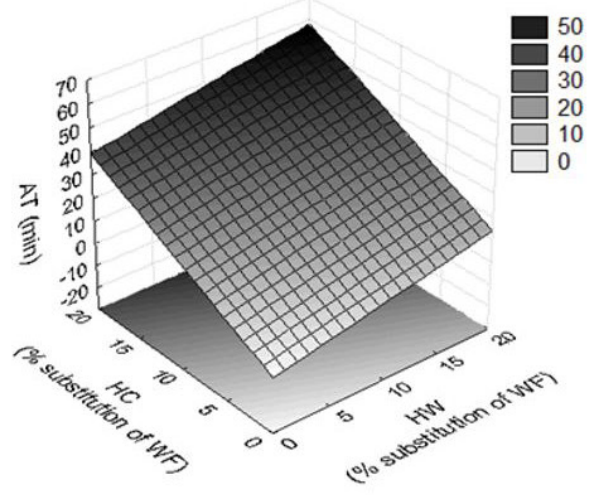

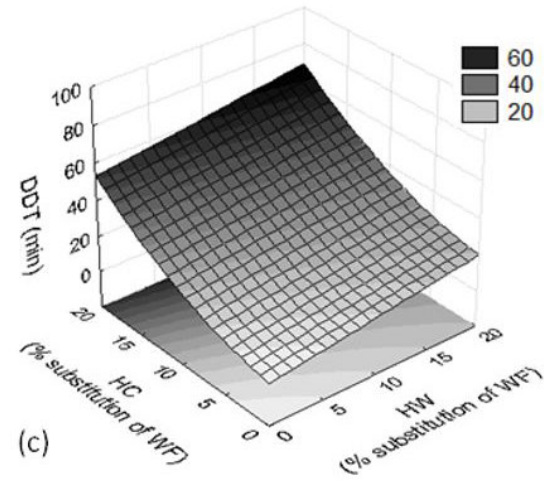

(d)

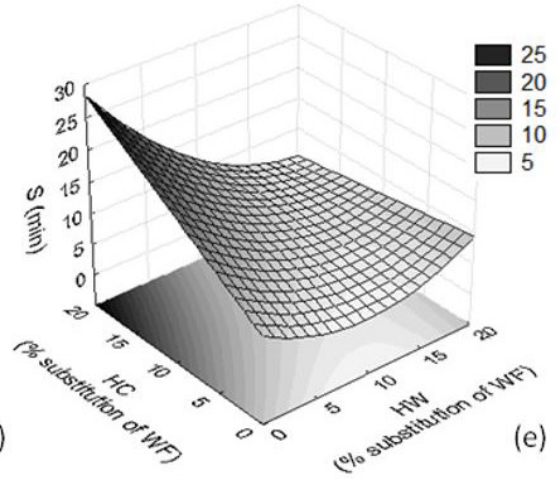

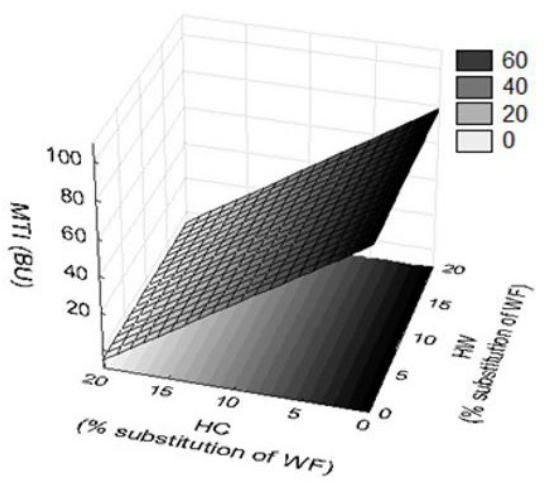

Figure 1. Response surfaces for farinograph parameters (a) WA: water absorption, (b) AT: arrival time, (c) DDT: dough development time, (d) S: stability and (e) MTI: mixing tolerance index, as a function of the substitution of wheat flour (WF) by whey (HW) and collagen (HC) protein hydrolysates.

order to achieve dough consistency. This result corroborates with those of Indrani et al. (2007) and Madenci \& Bilgiçli (2014), who also observed a decrease in WA while there was an increase in the amount of whey protein in WF. Gani et al. (2015a, b) also reported a decrease in the WA of WF dough by adding whey protein hydrolysates.

Arrival time (AT), a parameter associated with the hydration rate of wheat flour, was greater at high substitution percentages of HC and HW (Figure 1b) (ranging between 5.7 and 55 min for the tests, while being $1.4 \mathrm{~min}$ for the control) (Table 3 ). At higher substitution levels, we believe the hydrolysates hindered the absorption of water by wheat flour proteins, which led to a delay in hydration, and in the development of the gluten network. A longer time for the hydration of gluten proteins is required when other proteins are mixed with water and subjected to mechanical shear (Schmiele et al., 2017). At higher percentages of substitution of both hydrolysates $(>10 \%)$, it was possible to observe that flour hydration almost did not happen in the dough formation process, not enabling the conventional dough to take form, this way resulting in a more fluid dough. Gani et al. (2015b), despite working with smaller proportions (up to $15 \%$ ), also observed an increase in AT with the incorporation of hydrolyzed whey protein. The highest values of AT in our study can be associated with the addition of $\mathrm{HC}$, which showed greater influence on this parameter, thus intensifying this effect.
Both hydrolysates interfered in the dough development time (DDT), causing an increase in the values of this parameter (Figure 1c). For the enriched samples, DDT values ranged from 10.7 to $59.8 \mathrm{~min}$, while for the control the value was 14.4 (Table 3). This parameter is associated with the optimal time necessary to develop the gluten network. However, this increase was much higher than expected for wheat flour reference standards, which shows that, for this parameter, substitutions lower than $10 \%$ for each hydrolysate would be viable. Higher substitutions led to excessively high DDT, since there was a lower rate of hydration and, consequently, a delay in dough formation. Madenci \& Bilgiçli (2014) also reported an increase of DDT when adding 4 and $8 \%$ of whey protein concentrate.

Stability (S) increased only at low concentrations of HW and as $\mathrm{HC}$ also increased (Figure 1d). Despite this, when compared to the control test, the hydrolysates caused a weakening of the dough. This can be verified considering the values of 20.7 and 4.5 to $19.9 \mathrm{~min}$, for control and tests, respectively (Table 3). As in this study, Schmiele et al. (2017) also observed lower stability values, despite the increase in the values of DDT, working with hydrolyzed soy protein (0 to 20\% WF replacement). This phenomenon depends on the force of chemical linkages/interactions, which determine DDT. According to Schmiele et al. (2015), the hydrolysates may alter several interactions, such as ionic and hydrophobic interactions, covalent and hydrogen bonds, avoiding the total 
hydration of gluten proteins. Zadow (1981) studied the effect of adding whey protein concentrate to breads and observed a weaker and less elastic dough, resulting from the interference of sulfhydryl groups of the concentrate with disulfide/sulfhydryl reactions that occur in the development of the dough. Madenci \& Bilgiçli (2014) noted an increase in stability when incorporating 4 and $8 \%$ of whey protein concentrate. Gani et al. (2015a, b) also reported an increase in dough $\mathrm{S}$ after the addition of 5 and $10 \%$ of hydrolyzed whey protein. With $15 \%$, they observed a decrease in this parameter, as did Indrani et al. (2007), with the addition of more than $10 \%$ of whey protein concentrate.

Substitution of WF by HW did not influence the mixing tolerance index (MTI), while the substitution of WF by HC contributed to the decrease this parameter (Figure 1e). The lower values of MTI indicate a dough that tolerates overmixing. Thus, the presence of higher concentrations of $\mathrm{HC}$ seemed to contribute to this tolerance; however, as mentioned earlier, the doughs obtained at these concentrations are quite different regarding consistency when compared to that made only with WF. In addition, the results of this parameter may have been influenced by zero values attributed to the curves of tests F4 and F8, as described in Materials and Methods. The MTI values obtained ranged from 0 to $78.3 \mathrm{BU}$ for the tests; for the control, the value was of $43.3 \mathrm{BU}$ (Table 3 ).

In general, WA decreased and AT and DDT increased with both hydrolysates (HW and $\mathrm{HC}$ ) and S increased mainly with the addition of $\mathrm{HC}$ (nevertheless, it was below $S$ for pure flour). Even though some parameters may indicate dough "strengthening", we actually noticed its "weakening", as more fluid doughs were obtained, especially at high hydrolysate concentrations. We attribute these changes to the hindrance in water absorption by wheat flour proteins caused by the hydrolysates and to the differences in the characteristics of the dough when compared to pure flour.

Lupano (2000) states that whey proteins contribute to a viscous environment, just like gliadins in WF, thus affecting elasticity reduction in a similar way; but they could also form hydrogen and disulphide/glutenin bonds, interfering in the normal structure of gluten. This author also states that whey proteins "break" the gluten structure, i.e., gluten can be dispersed in a glass of distilled water just by adding whey protein concentrate.

This effect can be positive or negative, depending on the product in which the WF will be used. For example, this could be considered positive in the production of cookies, which require a weaker gluten structure in wheat flour doughs.

\section{Pasting properties}

The effect of different levels of hydrolysates of whey protein (HW) and collagen (HC) on pasting properties of wheat flour (WF) is presented in Table 5 and in Figure 2. All parameters presented mathematical models capable of showing the influence of the substitution of WF by HW and HC. These models can be observed in Table 6. In general, the hydrolysates caused an increase in the pasting temperature and a decrease in the other parameters, which was also observed by Chinma et al. (2015).

The pasting temperature is the parameter in which viscosity starts to increase during the heating process (Singh et al., 2011) due to starch gelatinization. Both hydrolysates increased the pasting temperature, but $\mathrm{HC}$ had a greater effect (Figure 2a). The temperatures for the tests, which ranged from 87.20 to $91.57^{\circ} \mathrm{C}$, were higher than for the control (pure WF), which was $85.58^{\circ} \mathrm{C}$. The higher pasting temperatures refer to the greater thermal energy required to break the starch-starch hydrogen bonds and form starch-water hydrogen bonds (starch gelatinization), influenced by the proteins in the hydrolysates that may compete for water to form their own gel. Indrani et al. (2007) also reported higher pasting temperatures with increased substitution of wheat flour by whey protein concentrate, as did Chinma et al. (2015) who studied the addition of protein concentrate from rice bran.

Maximum viscosity, represented by the viscosity peak, decreased with the addition of hydrolysates (Figure 2b). It ranged between 317 and $1530 \mathrm{cP}$ for the tests and it was of $1693 \mathrm{cP}$ for the control (Table 5). The viscosity of the wheat flour dough is mainly attributed to the gelatinization of starch granules, hence the decrease in viscosity observed for the premixes (addition of hydrolysates to WF) might be due to the dilution of starch (Wani et al., 2012; Chinma et al., 2015). In addition, since the

Table 5. Pasting properties as a function of the substitution of wheat flour by whey and collagen protein hydrolysates.

\begin{tabular}{|c|c|c|c|c|c|c|c|}
\hline Tests & $\begin{array}{c}\text { Pasting } \\
\text { temperature }\left({ }^{\circ} \mathrm{C}\right)\end{array}$ & $\begin{array}{c}\text { Maximum } \\
\text { viscosity }(\mathrm{cP})\end{array}$ & $\begin{array}{l}\text { Trough viscosity } \\
(\mathrm{cP})\end{array}$ & $\begin{array}{c}\text { Breakdown } \\
(\mathrm{cP})\end{array}$ & $\begin{array}{c}\text { Final viscosity } \\
(\mathrm{cP})\end{array}$ & $\begin{array}{c}\text { Setback } \\
(\mathrm{cP})\end{array}$ & $\begin{array}{c}\text { Peak time } \\
(\min )\end{array}$ \\
\hline 1 & $87.23 \pm 0.03$ & $1530 \pm 59$ & $818 \pm 50$ & $711 \pm 38$ & $2411 \pm 76$ & $1593 \pm 29$ & $5.73 \pm 0.07$ \\
\hline 2 & $89.47 \pm 0.58$ & $740 \pm 47$ & $428 \pm 23$ & $312 \pm 25$ & $1516 \pm 101$ & $1088 \pm 79$ & $5.24 \pm 0.04$ \\
\hline 3 & $90.22 \pm 0.45$ & $809 \pm 13$ & $534 \pm 23$ & $275 \pm 12$ & $1360 \pm 43$ & $827 \pm 24$ & $5.58 \pm 0.08$ \\
\hline 4 & $91.57 \pm 0.55$ & $317 \pm 24$ & $203 \pm 14$ & $113 \pm 10$ & $682 \pm 47$ & $479 \pm 33$ & $5.13 \pm 0.07$ \\
\hline 5 & $89.13 \pm 0.45$ & $1240 \pm 54$ & $713 \pm 38$ & $526 \pm 35$ & $2046 \pm 65$ & $1333 \pm 32$ & $5.73 \pm 0.07$ \\
\hline 6 & $90.50 \pm 0.00$ & $490 \pm 32$ & $298 \pm 17$ & $192 \pm 17$ & $1008 \pm 68$ & $710 \pm 53$ & $5.24 \pm 0.04$ \\
\hline 7 & $87.20 \pm 0.09$ & $1310 \pm 55$ & $686 \pm 33$ & $624 \pm 21$ & $2272 \pm 84$ & $1586 \pm 52$ & $5.49 \pm 0.04$ \\
\hline 8 & $91.48 \pm 0.41$ & $417 \pm 32$ & $318 \pm 23$ & $99 \pm 9$ & $830 \pm 43$ & $511 \pm 22$ & $5.27 \pm 0.00$ \\
\hline $9(\mathrm{C})$ & $89.92 \pm 0.43$ & $803 \pm 33$ & $524 \pm 14$ & $278 \pm 20$ & $1480 \pm 96$ & $955 \pm 82$ & $5.42 \pm 0.04$ \\
\hline $10(\mathrm{C})$ & $89.38 \pm 0.51$ & $843 \pm 27$ & $509 \pm 14$ & $334 \pm 14$ & $1527 \pm 53$ & $1018 \pm 39$ & $5.39 \pm 0.04$ \\
\hline $11(\mathrm{C})$ & $89.12 \pm 0.52$ & $852 \pm 27$ & $548 \pm 13$ & $304 \pm 18$ & $1535 \pm 73$ & $988 \pm 69$ & $5.38 \pm 0.04$ \\
\hline Control & $85.58 \pm 1.58$ & $1693 \pm 15$ & $965 \pm 38$ & $800 \pm 79$ & $2061 \pm 202$ & $1167 \pm 107$ & $5.84 \pm 0.25$ \\
\hline
\end{tabular}

Averages \pm standard deviations. Where: (C): central point; Control: pure wheat flour (without addition of hydrolysates). 
(a)

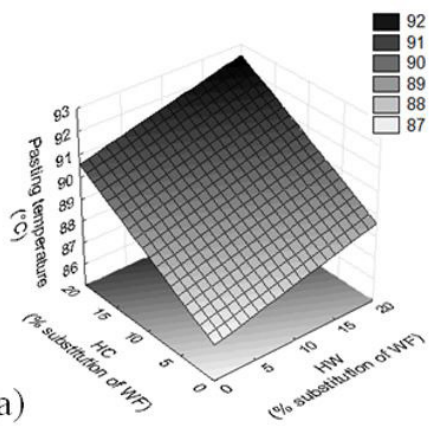

(b)

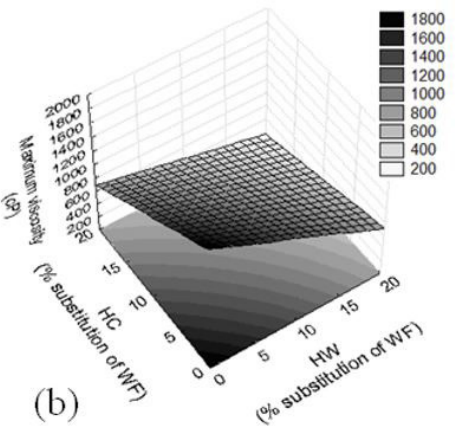

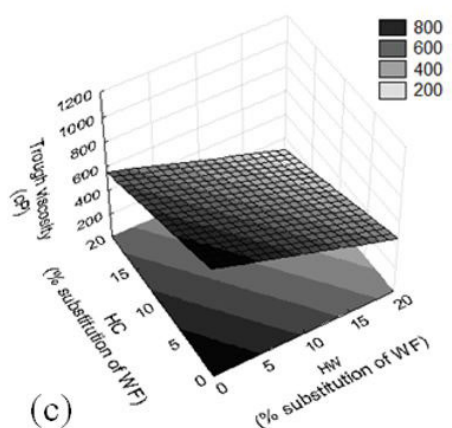

(c)

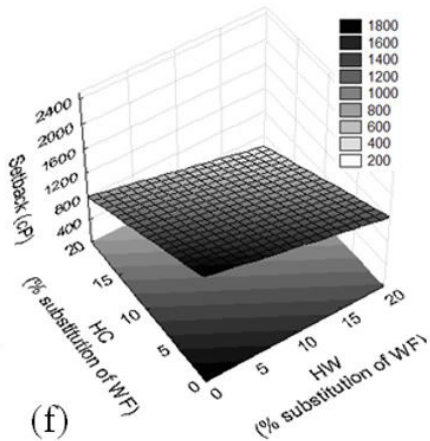

(g) (f)

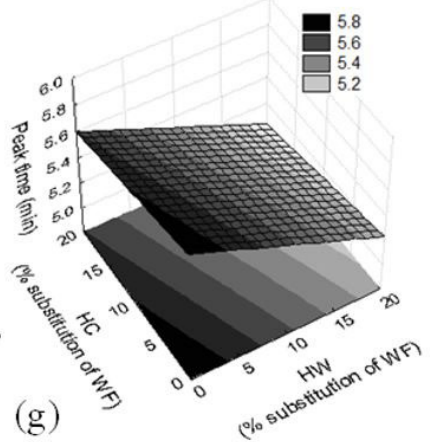

(e)

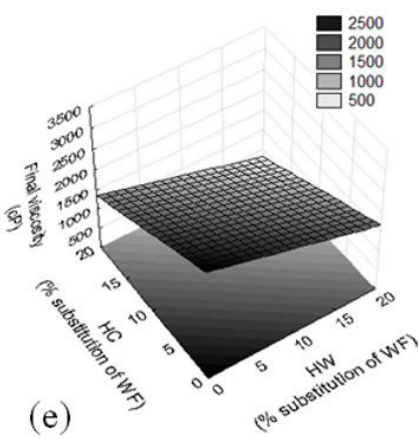

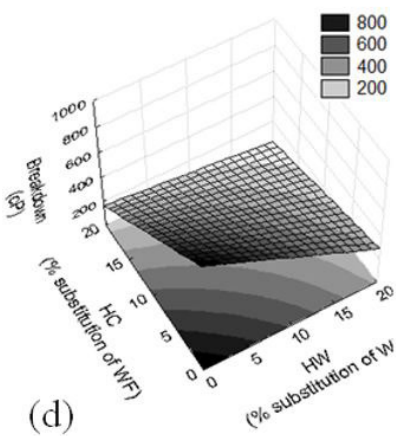

Figure 2. Response surfaces for pasting properties (a) pasting temperature, (b) maximum viscosity, (c) trough viscosity, (d) breakdown, (e) final viscosity, (f) setback and (g) peak time, as a function of the substitution of wheat flour (WF) by whey (HW) and collagen (HC) protein hydrolysates.

Table 6. Coded models for pasting properties as a function of the substitution of wheat flour by whey and collagen protein hydrolysates (coded values of independent variables must be used).

\begin{tabular}{cl}
\hline Parameters & \multicolumn{1}{c}{ Coded models } \\
\hline Pasting temperature $\left({ }^{\circ} \mathrm{C}\right)$ & $=89.57+0.69 \mathrm{x}_{1}+1.39 \mathrm{x}_{2}\left(\mathrm{R}^{2}=0.94 ;\right.$ Fcalc $/$ Ftab $\left.=13.84\right)$ \\
Maximum viscosity $(\mathrm{cP})$ & $=849.90-293.35 \mathrm{x}_{1}-301.25 \mathrm{x}_{2}+74.42 \mathrm{x}_{1} \mathrm{x}_{2}\left(\mathrm{R}^{2}=0.99 ;\right.$ Fcalc/Ftab $\left.=70.32\right)$ \\
Trough viscosity $(\mathrm{cP})$ & $=507.25-163.83 \mathrm{x}_{1}-128.79 \mathrm{x}_{2}\left(\mathrm{R}^{2}=0.98 ;\right.$ Fcalc/Ftab $\left.=55.77\right)$ \\
Breakdown $(\mathrm{cP})$ & $=342.65-129.52 \mathrm{x}_{1}-172.45 \mathrm{x}_{2+} 59.42 \mathrm{x}_{1} \mathrm{x}_{2}$ \\
Final viscosity $(\mathrm{cP})$ & $=1515.25-380.66 \mathrm{x}_{1}-491.26 \mathrm{x}_{2}\left(\mathrm{R}^{2}=0.99 ;\right.$ Fcalc/Ftab $\left.=120.56\right)$ \\
Setback $(\mathrm{cP})$ & $=1008.00-216.83 \mathrm{x}_{1}-362.46 \mathrm{x}_{2}\left(\mathrm{R}^{2}=0.99 ;\right.$ Fcalc/Ftab $\left.=77.19\right)$ \\
Peak time $(\mathrm{min})$ & $=5.42-0.20 \mathrm{x}_{1}-0.07 \mathrm{x}_{2}\left(\mathrm{R}^{2}=0.94 ;\right.$ Fcalc/Ftab $\left.=14.17\right)$ \\
\hline
\end{tabular}

$\mathrm{x}_{1}=$ coded value $(-\alpha$ to $+\alpha)$ of hydrolyzed whey protein $(\mathrm{HW})$ concentration in substitution percentage of wheat flour $(\mathrm{WF}) ; \mathrm{x}_{2}=$ coded value $(-\alpha$ to $+\alpha)$ of hydrolyzed collagen protein (HC) concentration in substitution percentage of wheat flour (WF); Fcalc = calculated F; Ftab = tabled F.

hydrolysates are soluble and of low molecular weight, and there is no correction in the water content during the analysis, the viscosity of the system decreases. Indrani et al. (2007) reported a reduction in maximum viscosity as the percentage of substitution of wheat flour by whey protein increased. As reported by Lorentz et al. (1979), with an increase in the substitution percentage of wheat flour by bean protein, there was a reduction in viscosity. As was observed for maximum viscosity, trough viscosity and final viscosity also decreased with the addition of hydrolysates, which might also be due to the dilution of starch in the mixture (Figures $2 \mathrm{c}$ and $2 \mathrm{e}$ ).

The breakdown and setback parameters were also influenced in a similar way. The substitution of WF by hydrolysates caused a reduction of their values (Figures $2 \mathrm{~d}$ and $2 \mathrm{f}$ ). Breakdown was $800 \mathrm{cP}$ for WF and for the samples with added hydrolyzed proteins ranged from 99 to $711 \mathrm{cP}$ (Table 5). Breakdown relates to the stability of starch granules when heated, under agitation. Starch granules, in the presence of water and heat, swell or gelatinize, and with continuous stirring, may be disrupted (Zeng et al., 1997; Leon et al., 2010). Schmiele et al. (2017) also observed lower $\mathrm{C} 4$ values in the Mixolab ${ }^{\mathrm{TM}}$ with higher levels of hydrolyzed soy protein, a parameter that also indicates the stability of the hot gel formed. Thus, somehow the hydrolysates interfered in this process, either because their presence led to a lower disruption of the granules and, consequently, increased their stability, or the results reflect a reduction in the concentration of starch in the sample.

The lower setback values observed (1167 cP for WF and 479 to $1593 \mathrm{cP}$ for the assays) demonstrate the action of the hydrolysates in reducing the tendency to retrograde. So they seem to help to delay the retrogradation process, a concern for some bakery products (like breads), but may also be a consequence 
of starch dilution. Schmiele et al. (2017) reported a significant anti-retrogradation effect of soy protein hydrolysate in breads, which would be of interest in preventing the staling of bakery products. Gani et al. (2015b) also found a decrease in breakdown and setback values when adding whey protein hydrolysate, as did Indrani et al. (2007) by adding whey protein concentrate.

Peak time, associated with the time needed to reach maximum viscosity in the mixture, was the parameter most affected by the substitution of WF by HW, since HC presented similar behavior in all concentrations regardless of the substitutions carried out with HW (Figure 2g). We observed a reduction in peak time with the increase of HW. In addition, we verified lower values of this parameter with higher substitution percentages of both hydrolysates. This is confirmed by the higher value of the control ( $5.84 \mathrm{~min}$ ) when compared to the other tests $(5.13$ to $5.73 \mathrm{~min}$ ) (Table 5).

As it can be observed, the parameters of maximum, trough and final viscosities, besides breakdown and setback, had their values reduced with the increase in the substitution of WF by hydrolyzed proteins (Figure 2 and Table 5), so that it is possible to say that hydrolysates interfere in the viscosity of the environment in which they are inserted (Lupano, 2000).

\section{Conclusion}

As expected, the amino acid composition for human consumption regarding essential amino acids proved to be excellent for HW and poor for HC. However, the two protein sources helped to improve the amino acid profile of WF, mainly contributing to supply lysine, the limiting amino acid of this ingredient.

Collagen and whey protein hydrolysates significantly affected the rheological characteristics of wheat flour, mainly due to water immobilization that caused a delay in the hydration of WF, and to the fact that they dilute gluten proteins and/or the starch that are present in WF. In the farinograph properties, HC showed greater influence, in theory leading to dough strengthening (using the values obtained for AT and DDT), but actually leading to its weakening (lower S, when compared to pure flour dough), once a more viscous and weak dough was obtained. For example, additions greater than $10 \%$ of hydrolysates would not allow the production of breads. However, this weakening can be considered positive in the production of some products, such as cookies, for which weaker wheat flours are required. The pasting properties were also influenced by the hydrolysates, which led to a decrease in all parameters, except for the pasting temperature, which was increased with their addition. The reduction caused by the hydrolysates in the setback parameter, for example, can indicate a delay in the retrogradation process, which would be of interest in preventing the staling of bakery products.

The rheological study of wheat flour doughs does not only predict behaviors in the production process of bakery products, but can also make it possible to evaluate and better explain the behavior of these protein sources that are still little studied. And regardless of the application, the doughs can be considered sources of protein, being a great step to obtain products with this same claim.

\section{Acknowledgements}

The authors thank CNPq [Conselho Nacional de Desenvolvimento Científico e Tecnológico (Brazilian National Counsel of Technological and Scientific Development)] and FAPESP [Fundação de Amparo à Pesquisa do Estado de São Paulo (São Paulo Research Foundation)] for research grants (CNPq Process numbers 140530/2015-0 and 307839/2016-8) and support (FAPESP Process numbers 2016/04034-5 and 2017/04519-1), and Espaço da Escrita - Coordenadoria Geral da Universidade - UNICAMP (Writing Space - General Coordination of the State University of Campinas) for the language services provided. We also thank the companies Bunge (Tatuí, BRA) and NovaProm (São Paulo, BRA) for the donations of wheat flour and hydrolyzed whey protein, respectively.

\section{References}

American Association of Cereal Chemistry International - AACCI. (2010). Approved methods of analysis (11st ed.). Saint Paul: AACC International.

Association of Official Analytical Chemists - AOAC. (2006). Official methods of analysis of Association of Official Analytical Chemists (17th ed.). Gaithersburg: AOAC International.

Brasil. Agência Nacional de Vigilância Sanitária. (2012, November 12). Regulamento técnico sobre informação nutricional complementar (RDC ANVISA n 54, de 12 de novembro de 2012). Diário Oficial [da] República Federativa do Brasil. Retrieved from http://portal. anvisa.gov.br/documents/\%2033880/2568070/rdc0054_12_11_2012. pdf/c5ac23fd-974e-4f2c-9fbc-48f7e0a31864

Cavalheiro, C. P., Lüdtke, F. L., Stefanello, F. S., Kubota, E. H., Terra, N. N., \& Fries, L. L. M. (2014). Replacement of mechanically deboned chicken meat with its protein hydrolysate in mortadella-type sausages. Food Science and Technology (Campinas), 34(3), 478-484. http:// dx.doi.org/10.1590/1678-457x.6370.

Chinma, C. E., Ilowefah, M., Shammugasamy, B., Mohammed, M., \& Muhammad, K. (2015). Effect of addition of protein concentrates from natural and yeast fermented rice bran on the rheological and technological properties of wheat bread. International Journal of Food Science \& Technology, 50(2), 290-297. http://dx.doi.org/10.1111/ ijfs.12619.

Damodaran, S., Parkin, K. L., \& Fennema, O. W. (2008). Fennema's food chemistry (4th ed.). Boca Raton: Taylor \& Francis Group.

Etzel, M. R. (2004). Manufacture and use of dairy protein fractions. The Journal of Nutrition, 134(4), 996S-1002S. http://dx.doi.org/10.1093/ jn/134.4.996S. PMid:15051860.

Foegeding, E. A., Luck, P., \& Vardhanabhuti, B. (2011). Whey protein products. In J. Fuquay, P. Fox, \& P. McSweeney (Eds.), The encyclopedia of dairy sciences (pp. 873-878). Oxford: Academic Press. http:// dx.doi.org/10.1016/B978-0-12-374407-4.00350-2 .

Food and Agriculture Organization - FAO, \& World Health Organization - WHO. (1985). Informe de una rede una reunión consultiva conjunta FAO/WHO/UNU de expertos. Necessidades de energia y de proteínas. Geneva: FAO.

Franco-Miranda, H., Chel-Guerrero, L., Gallegos-Tintoré, S., CastellanosRuelas, A., \& Betancur-Ancona, D. (2017). Physicochemical, rheological, bioactive and consumer acceptance analyses of concha-type Mexican sweet bread containing Lima bean or cowpea hydrolysates. Lebensmittel-Wissenschaft + Technologie, 80, 250-256. http://dx.doi.org/10.1016/j.lwt.2017.02.034. 
Gani, A., Broadway, A. A., Ahmad, M., Ashwar, B. A., Wani, A. A., Wani, S. M., Masoodi, F. A., \& Khatkar, B. S. (2015a). Effect of whey and casein protein hydrolysates on rheological, textural and sensory properties of cookies. Journal of Food Science and Technology, 59(2), 5718-5726. http://dx.doi.org/10.1007/s13197-014-1649-3. PMid:26344985.

Gani, A., Broadway, A. A., Masoodi, F. A., Wani, A. A., Maqsood, S., Ashwar, B. A., Shah, A., Rather, S. A., \& Gani, A. (2015b). Enzymatic hydrolysis of whey and casein protein- effect on functional, rheological, textural and sensory properties of breads. Journal of Food Science and Technology, 52(12), 7697-7709. http://dx.doi.org/10.1007/ s13197-015-1840-1. PMid:26604344.

Gerhardt, Â., Monteiro, B. W., Gennari, A., Lehn, D. N., \& Souza, C. F. V. (2013). Características físico-químicas e sensoriais de bebidas lácteas fermentadas utilizando soro de ricota e colágeno hidrolisado. Revista do Instituto de Latícinios Cândido Tostes, 68(390), 41-50. http://dx.doi.org/10.5935/2238-6416.20130007.

Hagen, S. R., Frost, B., \& Augustin, J. (1989). Precolumn phenylsothiocyanate derivatization chromatography of amino-acids in food and liquid. Journal - Association of Official Analytical Chemists, 72(6), 912-916. https://doi.org/10.1093/jaoac/72.6.912

Hood-Niefer, S. D., \& Tyler, R. T. (2010). Effect of protein, moisture content and barrel temperature on the physicochemical characteristics of pea flour extrudates. Food Research International, 43(2), 659-663. http://dx.doi.org/10.1016/j.foodres.2009.09.033.

Indrani, D., Prabhasankar, P., Rajiv, J., \& Rao, G. V. (2007). Influence of whey protein concentrate on the rheological characteristics of dough, microstructure and quality of unleavened flat bread (parotta). Food Research International, 40(10), 1254-1260. http:// dx.doi.org/10.1016/j.foodres.2007.08.005.

International Association for Cereal Science and Technology - ICC. (1996). Rapid pasting method using the Newport Rapid Visco Analyser. Wien: ICC Standard Methods.

Leon, E., Piston, F., Aouni, R., Shewry, P. R., Rosell, C. M., Martin, A., \& Barro, F. (2010). Pasting properties of transgenic lines of a commercial bread wheat expressing combinations of HMW glutenin subunit genes. Journal of Cereal Science, 51(3), 344-349. http://dx.doi. org/10.1016/j.jcs.2010.02.002.

Lorentz, K., Dilsaver, W., \& Wolton, N. (1979). Fava bean flour and protein concentrate in baked goods and in pasta products. Bakers Digest, 53(3), 39-49.

Lucas, B., \& Sotelo, A. (1980). Effect of alkalies, temperature and hydrolysis times on tryptophan determination of pure proteins and of food. Analytical Biochemistry, 109(1), 192-197. http://dx.doi. org/10.1016/0003-2697(80)90028-7.

Lupano, C. E. (2000). Gelation of mixed systems: whey protein concentrate - gluten in acidic conditions. Food Research International, 33(8), 691-696. http://dx.doi.org/10.1016/S0963-9969(00)00114-9.

Madenci, A. B., \& Bilgiçli, N. (2014). Effect of whey protein concentrate and buttermilk Powders on rheological properties of dough and
Bread quality. Journal of Food Quality, 37(2), 117-124. http://dx.doi. org/10.1111/jfq.12077.

Mahmoud, M. I. (1994). Physicochemical and functional properties of protein hydrolysates in nutritional products. Food Technology, $48,89-113$.

Menezes, J. M. B., Zambelli, R. A., Chinelate, G. C. B., Rodrigues, M. C. P., \& Pontes, D. F. (2014). Addition of collagen hydrolyzate in the quality of wheat flour for producing sliced Bread. Revista Brasileira de Agrotecnologia, 3(1), 10-22.

Nogueira, A. C. (2019). Enriquecimento proteico de biscoitos: utilização de diferentes hidrolisados e isolados proteicos (Tese de doutorado). Universidade Estadual de Campinas, Campinas.

Nunes, R. V., Rostagno, H. S., Albino, L. F. T., Gomes, P. C., \& Nascimento, A. H. (2001). Valores de aminoácidos digestíveis verdadeiros e equações de predição dos aminoácidos digestíveis do grão e de subprodutos do trigo para aves. Revista Brasileira de Zootecnia, 30(3), 774-784. http://dx.doi.org/10.1590/S1516-35982001000300024.

Ockerman, H. W., \& Hansen, C. L. (1994). Industrializacíon de subproductos de origen animal. Zaragoza: Acribia.

Prestes, R. C. (2013). Colágeno e seus derivados: características e aplicações em produtos cárneos. UNOPAR Científica. Ciências Biológicas e da Saúde, 15(1), 65-74.

Schmiele, M., Araújo, T. L., Gurgueira, M. D., \& Chang, Y. K. (2015). Determinação da concentração de diferentes sistemas de solventes na solubilização de proteínas de análogo de carne. Ciência Rural, 45(6), 1120-1125. http://dx.doi.org/10.1590/0103-8478cr20131630.

Schmiele, M., Felisberto, M. H. F., Clerici, M. T. P. S., \& Chang, Y. K. (2017). Mixolab ${ }^{\text {tw }}$ for rheological evaluation of wheat flour partially replaced by soy protein hydrolysate and fructooligosaccharides for Bread production. LWT - Food Science and Technology, 76(B), 259269. https://doi.org/10.1016/j.lwt.2016.07.014.

Singh, S., Singh, N., \& Macritchie, F. (2011). Relationship of polymeric proteins with pasting, gel dynamic- and dough empirical-rheology in different Indian wheat varieties. Food Hydrocolloids, 25(1), 19-24. http://dx.doi.org/10.1016/j.foodhyd.2010.05.001.

Wani, A. A., Sogi, D. S., Singh, P., Sharma, P., \& Pangal, A. (2012). Dough-handling and cookie-making properties of wheat flourwatermelon protein isolate blends. Food and Bioprocess Technology, 5(5), 1612-1621. http://dx.doi.org/10.1007/s11947-010-0466-6.

White, J. A., Hart, R. J., \& Fry, J. C. (1986). An evaluation of the Waters Pico-Tag system for the amino-acid analysis of food materials. Journal of Automatic Chemistry, 8(4), 170-177. https://doi.org/10.1155/ S1463924686000330

Zadow, J. G. (1981). Measurement of the effect of whey protein concentrates on fermenting dough by the Instron Tester. Australian Journal of Dairy Technology, 36, 56-59.

Zeng, M., Morris, C. F., Batey, I. L., \& Wrigley, C. W. (1997). Sources of variation for starch gelatinization, pasting, and gelation properties in wheat. Cereal Chemistry, 74(1), 63-71. http://dx.doi.org/10.1094/ CCHEM.1997.74.1.63. 